\author{
Pawel Czechowski, ${ }^{1}$ Adam Niewiadomski ${ }^{2}$
}

\title{
Wpływ funduszy strukturalnych na wzrost konkurencyjności polskiego rolnictwa - aspekty prawne
}

Celem badawczym projektu oraz artykułu „Wpływ funduszy strukturalnych na wzrost konkurencyjności polskiego rolnictwa" jest analiza konkurencyjności regionów w Polsce z punktu widzenia polskiego rolnictwa poprzez zbadanie efektywności wykorzystywania funduszy strukturalnych, ekonomicznej procedury ich podziału oraz podstaw prawno-organizacyjnych w ramach Programu Rozwoju Obszarów Wiejskich (PROW). Należy zwrócić uwagę, że tak zakreślona perspektywa badawcza ogranicza się do analizy tylko części funduszy strukturalnych przeznaczonych na wsparcie polskiego rolnictwa.

Podjęte badania, które objęły analizę spójności przepisów prawnych regulujących PROW, już na wstępnym etapie wskazują nie tylko praktyczne ekonomiczne efekty dysponowania środkami, ale przede wszystkim mają pokazać możliwe kierunki zmian w polskim prawie, zmierzające do właściwszego i sprawniejszego dysponowania przez administrację rolną funduszami strukturalnymi. Dla celów badawczych zanalizowano we wstępnym etapie 3 rozporządzenia unijne, 2 polskie ustawy, ponad 30 rozporządzeń resortowych, jedno obwieszczenie - PROW oraz kilkadziesiąt wybranych dokumentów o charakterze quasi-prawnym, takich jak wnioski i instrukcje dla potencjalnych beneficjentów. W następnej fazie badań analizie poddane zostaną dalsze akty prawne, przede wszystkim te najbardziej szczegółowe i kształtujące rzeczywistość prawną, czyli rozporządzenia resortowe.

W projekcie badawczym analizie zostaje poddany wpływ mechanizmów organizacyjno-prawnych na wydatkowanie funduszy strukturalnych na rozwój polskiego rolnictwa, a przede wszystkim na ich spójność z celami wspólnej polityki rolnej. Skuteczność regulacji prawnych decyduje w sposób istotny o ekonomicznej efektywności wykorzystania środków finansowych funduszy strukturalnych. Porównanie mechanizmów prawnych związanych z efektywnością wykorzystania 
Wpływ funduszy strukturalnych na wzrost konkurencyjności polskiego rolnictwa...

środków pochodzących z funduszy strukturalnych pozwoli nie tylko na lepszą realizację wspólnej polityki rolnej w regionach, ale przede wszystkim wskaże możliwość usprawnienia procesu administracyjnego rozdysponowywania tych środków.

Już wstępna analiza prawna wykazała, że proces rozdziału środków z funduszy strukturalnych UE wpłynął na wzrost konkurencyjności polskiego rolnictwa oraz jak zmienił polskie prawo rolne regulujące tę sferę działalności polskich rolników. Podjęto też próbę odpowiedzi na pytanie, czy rzeczywiste oddziaływanie polityki rolnej realizowanej także poprzez wydane normy prawne odpowiada deklarowanym celom.

Cele określające przeznaczenie funduszy strukturalnych określone są w Programie Rozwojów Wiejskich na lata 2007-2013. ${ }^{3}$ W 2004 r., po wstąpieniu do Unii Europejskiej w Polsce przyjęto Plan Rozwoju Obszarów Wiejskich na lata 2004-2006 w którym uregulowano takie ważne instrumenty prawne, jak np. renty strukturalne, zadania rolnośrodowiskowe, zalesianie gruntów, wsparcie tzw. obszarów o niekorzystnych warunkach gospodarowania (ONW), wsparcie dla grup producentów rolnych, pomoc techniczną. Obok Planu Rozwoju Obszarów Wiejskich obowiązywał jako część Narodowego Planu Rozwoju Sektorowy Program Operacyjny „Restrukturyzacja i modernizacja sektora żywnościowego i rozwoju obszarów wiejskich" (SPO), obejmujący m.in. scalanie gruntów rolnych, różnorodność działalności rolniczej w celu zapewnienia alternatywnych źródeł dochodów dla rolników. Szczegółowe efekty realizacji tych planów były już przedmiotem analiz ekonomistów.

Ewolucja polityki rozwoju obszarów wiejskich doprowadziła do przyjęcia 2007 r. Programu Rozwoju Obszarów Wiejskich na lata 2007-2013. W Polsce głównym źródłem prawa krajowego w zakresie polityki rozwoju obszarów wiejskich jest ustawa z dnia 7 marca 2007 r. o wspieraniu rozwoju obszarów wiejskich z udziałem środków Europejskiego Funduszu Rolnego na rzecz Rozwoju Obszarów Wiejskich, ${ }^{4}$ która określa zadania oraz właściwość organów i jednostek organizacyjnych w zakresie wspierania rozwoju obszarów wiejskich, warunki i tryb przyznawania, wypłaty oraz zwracania pomocy finansowej w ramach działań objętych PROW. Z pierwszym problemem natury prawnej, by nie użyć mocniejszych słów, natury konstytucyjnej spotykamy się już na wstępie naszych badań. PROW w Pol-

Projekt finansowany przez Narodowe Centrum Nauki. Obowiązujący PROW opublikowany został w obwieszczeniu Ministra Rolnictwa i Rozwoju Wsi z dnia 12 października 2007, w sprawie Programu Rozwoju Obszarów Wiejskich na lata 2007-2013, (M.P. Nr. 94, poz. 1035 ze zm.).

$4 \quad$ Dz.U. Nr 64, poz. 427 ze zm. Obok tej ustawy do podstawowych aktów prawnych regulujących omawianą problematykę można zaliczyć: ustawę z dnia 22 września 2006 r. o uruchamianiu środków pochodzących z budżetu Unii Europejskiej przeznaczonych na finansowanie wspólnej polityki rolnej (Dz.U. Nr 187, poz. 1381ze zm.); rozporządzenie Ministra Rolnictwa i Rozwoju Wsi z dnia 25 marca 2009 r. w sprawie warunków i sposobu przeprowadzania przez agencję płatniczą kontroli niektórych podmiotów wdrażających w zakresie wykonywania przez te podmioty zadań delegowanych w ramach Programu Rozwoju Obszarów Wiejskich na lata 2007-2013 (Dz.U. Nr 57, poz. 473); rozporządzenie Ministra Rolnictwa i Rozwoju Wsi z dnia 18 marca 2009 r. w sprawie podziału środków Programu Rozwoju Obszarów Wiejskich na lata 2007-2013 (Dz.U. Nr 48, poz. 388) oraz kilkadziesiąt rozporządzeń szczegółowych regulujących przyznawanie pomocy w poszczególnych działaniach. 
sce obowiązuje na podstawie obwieszczenia Ministra Rolnictwa i Rozwoju Wsi, które nie jest wymienione w konstytucyjnym katalogu źródeł prawa powszechnie obowiązującego. Wszystkie pozostałe rozporządzenia szczegółowe odnoszące się do poszczególnych działań odwołują się do PROW. Ta konstrukcyjna zawiłość budzi szereg wątpliwości prawnych, w szczególności jeżeli idzie o skuteczność stosowanych odesłań do PROW i konsekwencji prawnych związanych z niedostosowaniem się do wymagań obwieszczenia, które w żaden sposób nie może określać praw i obowiązków obywateli. Umiejscowienie Programu Obszarów Wiejskich w akcie prawnym niemającym charakteru prawa powszechnie obowiązującego należy ocenić sceptycznie z uwagi na wprowadzony zamęt i brak precyzyjnego określenia pozycji prawnej PROW.

Obok powyższej ustawy wydano kilka innych ustaw oraz kilkadziesiąt rozporządzeń, aby móc skutecznie rozdysponować przygotowaną pomoc z funduszy strukturalnych dla rolników. Należy zaznaczyć, że mamy do czynienia tutaj z ponad dwudziestoma działaniami o różnym, także inwestycyjnym, charakterze. Do każdego z działań wydano jedno podstawowe rozporządzenie regulujące tryb i zasady przyznawania pomocy oraz $\mathrm{w}$ miarę potrzeb inne rozporządzenia, mające na celu usprawnienie przekazywania środków oraz kontrolę ich wydatkowania. ${ }^{5}$ Wydano również szereg dokumentów o charakterze nienormatywnym, takich jak instrukcje, objaśnienia. Tego typu informacje mają sprzyjać w zrozumieniu aktów prawnych przez rolników. W większości przypadków spełniają tak postawione zadanie. Zauważyć jednak należy, że zdarzają się sytuacje, kiedy zachodzi rozbieżność pomiędzy treścią instrukcji a obowiązującym dla danego działania rozporządzeniem.

Poddane wstępnej analizie akty prawne wykazały, że zasady przyznawania i rozdziału środków pomocy są poprawne. W sprawach najważniejszych poprawnie recypowano do prawa polskiego zapisy regulacji europejskich, zarówno poddając ocenie procedurę przyznawania pomocy, jak też i określanie kręgu beneficjentów. Ta pozytywna ocena regulacji o charakterze podstawowym nie pozwala jednak dokonać pozytywnej oceny całości prawodawstwa określającego rozdział funduszy strukturalnych dla polskiego rolnictwa.

Dla przykładu można tutaj wymienić: rozporządzenie Ministra Finansów z dnia 13 grudnia 2006 r. w sprawie warunków i trybu współpracy ministra właściwego do spraw finansów publicznych z jednostką koordynującą oraz audytorem wewnętrznym agencji płatniczej (Dz.U. Nr 239, poz. 1730); rozporządzenie Ministra Rolnictwa i Rozwoju Wsi z dnia 6 grudnia 2006 r. w sprawie zakresu, trybu, formy oraz terminów przekazywania przez agencje płatnicze danych finansowych i informacji jednostce koordynującej (Dz.U. Nr 229, poz. 1674); rozporządzenie Rady Ministrów z dnia 12 sierpnia 2008 r. w sprawie pożyczek z budżetu państwa na wyprzedzające finansowanie w ramach programu rozwoju obszarów wiejskich (Dz.U. Nr 156, poz. 968); rozporządzenie Ministra Finansów z dnia 3 marca 2009 r. w sprawie przekazywania na rachunek bankowy agencji płatniczej środków na realizację wspólnej polityki rolnej (Dz.U. Nr 40, poz. 325); rozporządzenie Ministra Finansów z dnia 9 listopada 2006 r. w sprawie przyznania Agencji Restrukturyzacji i Modernizacji Rolnictwa akredytacji jako agencji płatniczej w zakresie uruchamiania środków pochodzących z Europejskiego Funduszu Rolniczego Gwarancji oraz Europejskiego Funduszu Rolniczego Rozwoju Obszarów Wiejskich (Dz.U. Nr 204, poz. 1506 ze zm.). 
Wpływ funduszy strukturalnych na wzrost konkurencyjności polskiego rolnictwa...

Poważnym utrudnieniem prawnym jest duża liczba zmian rozporządzeń regulujących przyznawanie pomocy. Przykładowo rozporządzenie dotyczące rent strukturalnych było zmieniane w latach 2007-2010 sześciokrotnie, co daje przeciętnie dwie zmiany rocznie. Jak na tak krótki akt prawny ilość zmian, przeprowadzana w trakcie trwania procesu przyznawania pomocy, jest znaczna. Kwestią najtrudniejszą pozostają tutaj dość nieprecyzyjne przepisy intertemporalne. Poza tym zmiana PROW i zmiana rozporządzeń nie odbywają się w tym samym czasie. Przez kilka miesięcy mamy do czynienia z rozbieżnością zaktualizowanego PROW i jeszcze z nienowelizowanym rozporządzeniem. Ze zrozumieniem należy przyjąć skomplikowaną procedurę zmiany PROW i niepewność co do ostatecznego kształtu zmian zależnego od władzy europejskiej. Te zmiany jednak nie mogą powodować opóźnień w ich wprowadzaniu w regulacjach dotyczących poszczególnych działań. Podobne częste zmiany można zaobserwować w pozostałych aktach prawnych dotyczących przyznawania pomocy materialnej. Sama ustawa była zmieniana już siedmiokrotnie. Ze zrozumieniem należy przyjąć wyjaśnienia prawodawcy wskazujące na zmieniające się prawo europejskie oraz konieczność nowelizacji ze względu na zmieniającą się wielkość pomocy finansowej. Wskazać jednak należy, że duża ilość zmian nie wynika tylko z tych dwóch przyczyn i w znacznej części jest wynikiem realizowania bieżącej polityki rolnej lub też, co trzeba przyznać, poprawiania kolejnych błędów legislacyjnych. Zmiany te nie są tylko czysto kosmetyczne, ale niejednokrotnie kompletnie zmieniają zasady przyznawania pomocy, określają inaczej krąg beneficjentów, a także ustalają wielkość otrzymanej pomocy na zupełnie innych poziomach. Tego typu zmiany, połączone z dość niejasnymi przepisami przejściowymi, w przypadkach jeżeli są wprowadzane, powodują chaos prawny, a tym samym destabilizację prawa. Należy zalecić wprowadzanie tylko zmian koniecznych i to tylko tych, które mogą wpłynąć na większą efektywność danego działania. Stabilność prawa regulującego sferę prawno-gospodarczą stanowi wartość wiodącą. Dość wspomnieć, że duża część spraw sądowych podejmowanych przez niezadowolonych potencjalnych beneficjentów lub beneficjentów dotyczy zmieniającego się prawa oraz jego niejasnej interpretacji. Ilość wytaczanych powództw oraz zgłaszanych roszczeń powinna niepokoić, w szczególności mając w pamięci relację czasową pomiędzy długością rozpatrywania spraw w sądzie a szybkością przyznawanej pomocy z funduszy strukturalnych

Obok kwestii nadmiernej ilości zmian jako podstawowe problemy prawne natury legislacyjnej i spójności systemu prawnego należy wskazać potrzebę uporządkowania zawartych w rozporządzeniach pojęć, w szczególności definicji legalnych (np. w rozporządzeniu dotyczącym działania Ułatwianie startu młodym rolnikom w § 2 ust. 1 pkt 1 w sposób nieprecyzyjny określa się wymóg dotyczący powierzchni 1 ha użytków rolnych nieruchomości), potrzebę dostosowania niektórych przepisów do aktualnie obowiązującego PROW (jeden z przykładów zostanie podany w dal- 
szej części artykułu), potrzebę zmiany niektórych przepisów w celu uniknięcia pojawiających się w związku z ich brzmieniem wątpliwości. Tutaj jako przykład można podać regulacje zawarte w $\S 18$ ust. 1 pkt 5 rozporządzenia dotyczącego działania Ułatwianie startu młodym rolnikom. Zawarty tam obowiązek podlegania ubezpieczeniu społecznemu rolników nie wynika z przepisów wspólnotowych. Zastosowanie tego wymogu może stanowić ograniczenie dla grupy osób, które chcą rozpocząć prowadzenie działalności rolniczej, jednak nie mogą podlegać ubezpieczeniu rolniczemu wynikającemu z mocy ustawy. Podejmowane zaostrzenia na mocy wyników negocjacji z Komisją Europejską nie mogą być jedynym wyznacznikiem realizacji zamierzeń prawodawcy.

Tego typu działania powinny doprowadzić do zwiększenia komplementarności poszczególnych przepisów i usunięcia istniejących wewnętrznych sprzeczności.

Szeregu doprecyzowań i usunięcia błędów wymagają jednak rozwiązania szczegółowe, które zostaną tutaj wskazane jedynie sygnalnie, aby uzyskać pełne rozwinięcie w pracy końcowej będącej efektem podjętych badań. Proponowane zmiany szczegółowe mają różny charakter i zakres. Jedne wprost wskazują błędy, które stanowią poważne usterki prawne, niektóre z nich zostały wskazane powyżej, drugie pokazują rozbieżności pomiędzy poszczególnymi aktami i dokumentami, jeszcze inne wskazują tylko uchybienia i usterki natury porządkowej i redakcyjnej.

Jako przykład tego typu zjawiska wskazać można regulacje dotyczące jednego z najbardziej popularnych działań „Modernizacja gospodarstw rolnych”. W § 2 ust. 1 pkt 4 rozporządzeni dotyczącego tego działania wprowadza się ograniczenie wiekowe dla osoby fizycznej, która może ubiegać się o pomoc. Wskazać należy, że ani przepisy wspólnotowe, ani PROW, który wskazuje, że osoba fizyczna jest pełnoletnia i nie osiągnęła wieku emerytalnego, nie wprowadzają wprost takiego ograniczenia. Przy założeniu, że przez wiek emerytalny zawarty w PROW wnioskodawca ma rozumieć zgodnie z art. 19 ust. 1 pkt 1 ustawy z dnia 20 grudnia 1990 o ubezpieczeniu społecznym rolników (tekst jedn. Dz.U. z 2008 r. Nr 50, poz. 291 ze zm.), który stanowi, że „Emerytura rolnicza przysługuje ubezpieczonemu, który spełnia łącznie następujące warunki: osiągnął wiek emerytalny; wiek emerytalny kobiety wynosi 60 lat, a mężczyzny 65 lat"; należy rozważyć zmianę tego zapisu w rozporządzeniu, dostosowując go do wymogów PROW w zgodzie z obowiązującymi przepisami o ubezpieczeniu społecznym rolników i rozumieniu wieku emerytalnego rolnika w myśl tej ustawy. W tym przypadku wprowadzona regulacja może być uznana za sprzeczną z regulacją ustawową.

Innym przykładem dotyczącym tego samego działania może być regulacja zawarta w $\S 2$ ust. 1 pkt 1, która wprowadza, podobnie jak w innych działaniach, wymóg osiągnięcia nadwyżki bezpośredniej z działalności rolniczej o wartości co najmniej 4 ESU. Pomijając fakt, że duża część rolników nie wie, jaka jest rzeczywista 
Wpływ funduszy strukturalnych na wzrost konkurencyjności polskiego rolnictwa...

wielkość tej jednostki, należy zwrócić uwagę, że stosowanie tej wartości wydaje się być czasochłonne dla wnioskodawcy i dosyć trudne, pomimo zastosowania systemu objaśnień w instrukcjach przygotowanych przez Agencję Restrukturyzacji i Modernizacji Rolnictwa.

Należałoby rozważyć, czy w tym zakresie nie należałoby zmienić rozwiązań zawartych w PROW poprzez zwiększenie wagi opisu rozwoju gospodarstwa zawartego w Planie Rozwoju Gospodarstwa (PRG). Dane tam zawarte w wystarczający sposób dokumentują żywotność gospodarstwa pod względem ekonomicznym, dotyczą też każdego indywidualnego gospodarstwa. Raz opracowany plan dla jednego działania mógłby być tylko modyfikowany pod kątem kolejnych wniosków pomocowych i stanowiłby podstawę przyznawania pomocy. Takie rozwiązanie nie tylko przyspieszy proces przyznawania pomocy dla rolników, ale pozwoli zapobiec istnieniu kilku rozbieżnych Planów Rozwojów Gospodarstwa w odniesieniu do jednej i tej samej jednostki produkcyjnej.

Kwestią wymagającą jasnego określenia jest również sprawa wzajemnych relacji europejskich i polskich regulacji sieci Natura 2000 oraz programów pomocowych, w szczególności programów rolnośrodowiskowych. Uregulowana w rozporządzeniu Ministra Rolnictwa i Rozwoju Wsi z dnia 26 lutego 2009 r. w sprawie szczegółowych warunków i trybu przyznawania pomocy finansowej w ramach działania „Program rolnośrodowiskowy” objętego PROW na lata 2007-2013 (Dz.U. Nr 33, poz. 262 z późn. zm.) procedura ubiegania się o pomoc z tego działania wymienia jako jeden $\mathrm{z}$ pakietów, w ramach którego realizowane są zobowiązania rolnośrodowiskowe - Pakiet 5. Ochronę gatunków ptaków i siedlisk przyrodniczych na obszarach Natura 2000. Opisane w rozporządzeniu wymagania w pewnych częściach powtarzają elementy planów zadań ochronnych. Zawartość sporządzanych przez potencjalnych beneficjentów planów działalności rolnośrodowiskowych, w szczególności w zakresie opisu siedliska przyrodniczego lub siedliska lęgowego ptaków, planów wypasów przy użytkowaniu pastwiskowym lub kośno-pastwiskowym (załącznik nr 1 część II pkt 4 powyżej przywołanego rozporządzenia), może okazać się tożsama z opisem występowania przedmiotów ochrony przyrody oraz opisem ich stanu, zagrożeń, wymogów i możliwości ochrony przyrody, a także z opisem uwarunkowań geograficznych, przyrodniczych zawartych w planach zadań ochronnych (§ 3 pkt 2 lit. b-c rozporządzenia Ministra Ochrony Środowiska z dnia 17 lutego 2010 r. w sprawie sporządzania projektu planu zadań ochronnych dla obszaru Natura 2000 - Dz.U. Nr 34, poz. 186). Takie wymagania, których indywidualna analiza jest dość kosztochłonna dla potencjalnego beneficjenta, mogą ograniczyć możliwości ubiegania się o pomoc. W celu uproszczenia procedury i bardziej ejektywnego wykorzystywania aktu prawa miejscowego, jakim jest plan zadań ochronnych, należy postulować rozważenie doprowadzenia do komplementarności w głównych możliwych elementach planów działalności rolnośrodowiskowej oraz planów zadań 
ochronnych. Postulować należy, aby elementy określone w planach zadań ochronnych mogły być bezpośrednio wykorzystywane i aby móc się do nich odwoływać przy sporządzaniu planu działalności rolnośrodowiskowej. Określone w planach zadań ochronnych opisy przedmiotów ochrony - siedlisk przyrodniczych powinny być częścią planu działalności rolnośrodowiskowej. Beneficjent powinien je wykorzystywać jako akt prawa miejscowego sporządzony w skomplikowanej procedurze przez fachowców. Wprowadzenie powiązania zawartości planów zadań ochronnych z zawartością planu działalności rolnośrodowiskowej może ułatwić proces absorpcji środków pomocowych.

Kolejnym problemem wynikającym na tym etapie prowadzonych badań jest niespójność PROW z obowiązującymi rozporządzeniami. Rozumiejąc skomplikowaną procedurę uchwalania PROW oraz istniejące $\mathrm{w}$ wyniku tych zmian różnice w czasie zmieniania PROW i następczego zmieniania rozporządzeń, należy wskazać, że niektóre z przewidzianych w rozporządzeniach obowiązków i wymagań nie znajdują uzasadnienia zarówno w przepisach prawa wspólnotowego, jak też w PROW. Mając tę obserwację na uwadze, należałoby jak najszybciej usunąć istniejące sprzeczności poprzez wprowadzenie zmian $w$ rozporządzeniach. Ponadto, także niektóre $\mathrm{z}$ rozwiązań przewidzianych w PROW są wynikiem przyjętych założeń i dopuszczalna jest ich modyfikacja, przy czym w tym wypadku konieczne jest uprzednie uzgodnienie zmian z Komisją Europejską, co wpływa także na niestabilność prawa. Ta modyfikacja jest tym bardziej wskazana przy następnym okresie planowania.

W celu usprawnienia procesu rozdziału środków pomocowych zarówno w bieżącym, jak i przyszłym okresie programowania należałoby rozważyć skrócenie terminów przewidzianych na różne czynności proceduralne w procesie przyznawania pomocy, tak aby przyspieszyć proces jej przyznawania. Analizując wytyczne zawarte w PROW oraz rzeczywisty czas potrzebny do obsługi wniosku, należy rozważyć ewentualne skrócenie niektórych terminów proceduralnych ze strony przede wszystkim Agencji rozpatrującej wnioski. Niektóre z tych terminów są znacznie dłuższe, niż przewiduje to Kodeks postępowania administracyjnego. Dla przykładu - rolnicy, po przygotowaniu poprawnego wniosku, oczekują szybkich decyzji i szybkiego wsparcia finansowego. Długotrwałość procesu przyznawania pomocy niekiedy prowadzi do jego nieefktywności. Skrócenie terminów powinno przynieść przyspieszenie, którego oczekują potencjalni beneficjenci. Przy skracaniu terminów należy jednak dokładnie rozważyć zasadność poszczególnych czynności i ocenić ilość potrzebnego czasu na ich dokonanie. Racjonalne dostosowanie terminów do zmieniającej się rzeczywistości pozwoli na szybsze rozpatrywanie spraw, nie powodując jednocześnie zarzutów przewlekłości i stronniczości postępowania.

Zaobserwowano również niekonsekwencję w regulacji ilości wymaganych danych od potencjalnego beneficjenta. Przykładowo, biorąc pod uwagę wymo- 
Wpływ funduszy strukturalnych na wzrost konkurencyjności polskiego rolnictwa...

gi sprawozdawczości, monitoringu i innych przepisów, należy zastanowić się, czy te wszystkie informacje powinny być wymagane we wnioskach. Wiążący charakter wniosku objęty pewnymi sankcjami prawnymi powoduje też to, że te dane powinny być weryfikowalne. Zaleca się, aby te dane znalazły się poza najważniejszymi dokumentami. Zabieg ten powinien usprawnić proces wypełniana wniosków i ich odpowiednie skrócenie. Obecnie wypełnianie kilkudziesięciostronicowych wniosków sprawia spore trudności. Rozważyć również należy zasadność stosowania wszystkich zalecanych załączników. Część z nich może zostać włączona do samego formularza wniosku, co spowoduje, iż zasadniczo zostanie ograniczona ilość wypełnianych dokumentów, a część z nich może zostać skrócona do niezbędnego minimum.

Wskazać należy również na rozbudowaną biurokratyzację procesu uzyskiwania pomocy, a później uzyskiwania płatności. Nie wszystkie rozwiązania są konsekwencją wymagań unijnych. Biurokratyzacja tego procesu wymaga również utrzymywania rozbudowanej struktury Agencji Restrukturyzacji i Modernizacji Rolnictwa.

Odnosząc się tylko sygnalnie do innych możliwości wykorzystywania funduszy strukturalnych w rolnictwie, należy się zastanowić, dlaczego nie wszyscy rolnicy sięgają po te pieniądze. Dla przykładu o pomoc, którą można otrzymać najprościej, czyli tzw. dopłaty bezpośrednie, ubiega się tylko 1,4 mln beneficjentów z 2,1 mln gospodarstw w Polsce.

Reasumując powyższe rozważania można wskazać główne kierunki zmian. Wiele przyjętych w PROW, a w konsekwencji i w krajowych rozporządzeniach, rozwiązań nie wynika wprost z przepisów wspólnotowych, a niejednokrotnie w mniejszym lub większym stopniu ograniczają one dostęp do pomocy (co nierzadko jest zabiegiem celowym ustalonym z Komisją Europejską, wynikającym z potrzeby realizacji celów stawianych poszczególnym działaniom). Dokonana szczegółowa analiza poszczególnych aktów prawnych wskazuje, że takie zmiany zwiększające efektywność są możliwe. W toczonej debacie na temat przyszłości Wspólnej Polityki Rolnej, a przede wszystkim w negocjacjach dotyczących wysokości uzyskiwanej pomocy, należy wziąć pod uwagę proponowane zmiany i w sposób racjonalny wprowadzić je w życie. 


\section{STRUCTURAL FUNDS INCREASE THE COMPETITIVENESS OF POLISH AGRICULTURE - LEGAL ASPECTS}

Key words: Structural Funds, Polish regions, rural development.

The authors present the results of the research project „The Impact of Structural Funds to increase the competitiveness of Polish agriculture." They analyze the competitiveness of Polish regions from the point of view of Polish agriculture by examining the effectiveness of the Structural Funds, the allocation of economic process and the legal and organizational framework of the Rural Development Programme (RDP). They note that their research is limited to the analysis only to a part of the Structural Funds which support Polish agriculture.

The study, which included analysis of the consistency of the laws governing the RDP, at the initial stage, show not only practical economic effects of the disposal of funds, but also show the possible directions of changes in Polish law aimed at more appropriate and efficient disposal of agricultural administration of the Structural Funds. 